\section{Low plasma cortisol concentrations during late asthmatic responses}

Plasma cortisol concentrations in relation to late asthmatic responses after inhalation of allergen have not been reported. We measured serial plasma cortisol concentrations in various types of asthmatic responses.

\section{Patients, methods, and results}

Thirteen atopic patients with asthma volunteered to take part in the study. All had a history of episodic dyspnoea with wheezing or chest tightness on exposure to allergens (house dust, Candida albicans, and wheat flours). None had received corticosteroids therapeutically. Allergen inhalation tests showed that five of the patients had late asthmatic responses alone, four had immediate asthmatic responses alone, and the remainder had both immediate and late responses.

Heparinised blood samples were obtained before challenge, one and five hours after challenge, and during paroxysm. Plasma cortisol concentrations
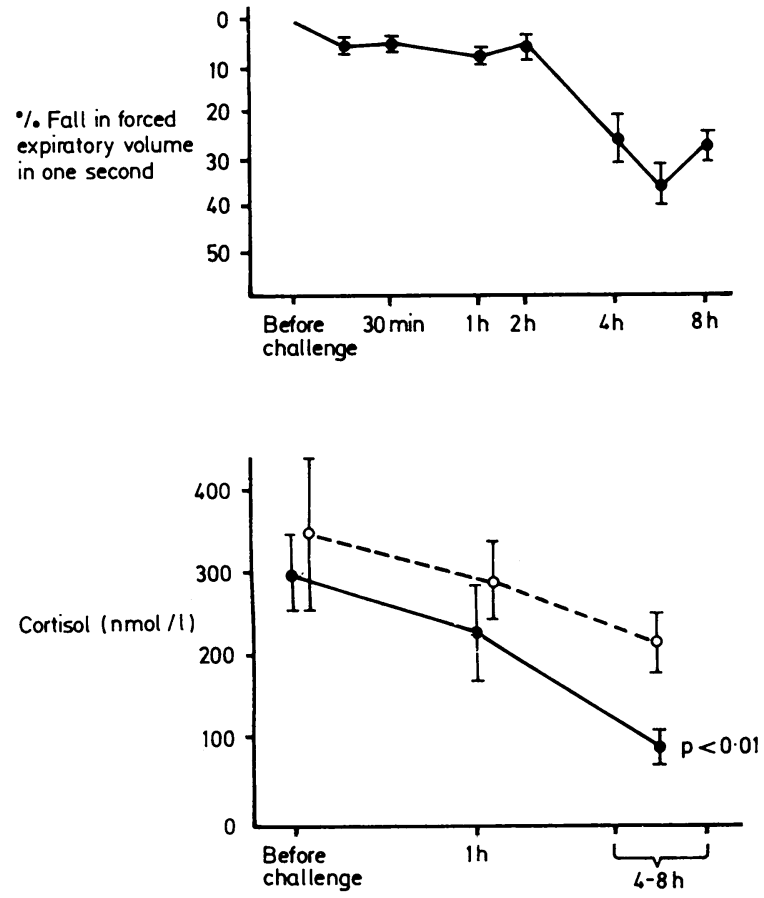

Serial changes in mean (SEM) plasma cortisol concentrations in five patients who showed late asthmatic responses alone related to changes in forced expiratory volume in one second. Broken line indicates diurmal plasma cortisol concentrations over same period measured on another day without any inhalation. Concentrations during late responses were significantly lower than these normal concentrations $(p<0.01)$

Conversion: $S I$ to traditional units-Cortisol: $1 \mathrm{nmol} / 1 \approx 0.036$ $\mu \mathrm{g} / 100 \mathrm{ml}$

were measured by radioimmunoassay based on a competitive binding principle using a gamma coat iodine-125 cortisol radioimmunoassay kit (Travenol, USA). ${ }^{1}$

The two types of asthmatic response showed different patterns of cortisol concentrations: concentrations increased slightly during immediate asthmatic responses whereas they decreased during late asthmatic responses. In the five patients who showed a late response the mean cortisol concentration fell from $301(44) \mathrm{nmol} / \mathrm{l}(10.9(1.6) \mu \mathrm{g} / 100 \mathrm{ml})$ before challenge to 232 (61) $\mathrm{nmol} / \mathrm{l}(8 \cdot 4(2 \cdot 2) \mu \mathrm{g} / 100 \mathrm{ml})$ at one hour and to $97(22) \mathrm{nmol} / 1(3.5(0.8)$ $\mu \mathrm{g} / 100 \mathrm{ml}$ ) during the late response. The concentration during the late response was significantly lower than the normal concentration over the same period $(p<0.01)$ (figure). In the four patients who showed both immediate and late responses the mean cortisol concentration increased slightly from $265(25) \mathrm{nmol} / \mathrm{l}(9.6(0.9) \mu \mathrm{g} / 100 \mathrm{ml})$ before inhalation to $290(41) \mathrm{nmol} / \mathrm{l}$ $(10.5(1.5) \mu \mathrm{g} / 100 \mathrm{ml})$ during the immediate response and then fell to 179 (25) $\mathrm{nmol} / \mathrm{l}(6.5(0.9) \mu \mathrm{g} / 100 \mathrm{ml})$ one hour later and to $116(14) \mathrm{nmol} / \mathrm{l}$ $(4.2(0.5) \mu \mathrm{g} / 100 \mathrm{ml})$ during the late response. The concentration during the late response was again lower than the normal concentration over the same period $(p<0.005)$. In the group who showed only an immediate response the mean cortisol concentration was $354(41) \mathrm{nmol} / 1(12.8(1.5) \mu \mathrm{g} / 100 \mathrm{ml})$ before challenge, $356(41) \mathrm{nmol} / \mathrm{l}(12.9(1.5) \mu \mathrm{g} / 100 \mathrm{ml})$ during the immediate attacks,
$378(41) \mathrm{nmol} / 1(13.7(1.5) \mu \mathrm{g} / 100 \mathrm{ml})$ after one hour, and $334(72) \mathrm{nmol} / \mathrm{l}$ $(12 \cdot 1(2 \cdot 6) \mu \mathrm{g} / 100 \mathrm{ml})$ after five hours. These concentrations were not significantly different from normal values over the same period.

\section{Comment}

The pathophysiological mechanism of late asthmatic responses is still obscure, but premedication with corticosteroids inhibits the development of such responses. ${ }^{2} 3$ This phenomenon caused us to speculate that if adrenal production of steroids is insufficient to block late asthmatic responses the function of the adrenal glands in producing endogenous steroids may be the basis for the responses."

We found that plasma cortisol concentrations were appreciably decreased during late asthmatic responses. This decrease was considered to be specific to late responses as it occurred consistently in the group who showed a late response and during late responses in the group who showed both late and immediate responses but it did not occur during immediate attacks. Moreover, it was a transient phenomenon, concentrations a few days after the test being normal. These findings seem to support our hypothesis, although the reason why the phenomenon was induced could not be explained. Robson and Kilborn reported a reduction in adrenocortical reserve during attacks in continuous asthma. ${ }^{5}$ As the mechanics of the lung in late asthmatic responses are similar to those in continuous asthma a similar reduction in adrenocortical reserve may occur. The pathophysiology of late responses has not been determined, although they have been attributed to several causes-namely, the generation of factors derived from mast cells, the activation of the coagulation cascades, and arachidonic acid products. This study will be of some value in giving a new direction to further research on late asthmatic responses.

1 Oseko F, Ikeda F, Kono T, Terashima S, Imura H. Studies on gamma coa ${ }_{125}$ I cortisol kit for clinical application. Clin Endocrinol 1980;28:149-54 2 Pepys J. Immunopathology of allergic lung disorders. Clin Allergy 1976;3:1-12. Nakazawa $T$, Toyoda $T$, Furukawa $M$, Kobayashi $S$. Inhibitory effects of various drugs on dual asthmatic responses in wheat four-sensitive patients. $\mathcal{f}$ Allergy Clin Immunol 1976;58:1-9.

4 Nakazawa T. Changes of plasma cortisol level in late asthmatic responses. Arerugi $1984 ; 33: 424-7$.

Thorax 1965;20:92 $\mathrm{R}$. Studies of adrenocortical function in continuous asthma.

Accepted 5 fuly 1985)

First Department of Internal Medicine, Gunma University, School of Medicine, Maebashi, Gunma, Japan 371

TSUGIO NAKAZAWA, MD, assistant professor

YOSHIO UMEGAE, MD, teaching associate

SHIGERU MATSUI, MD, teaching associate

SETSUO KOBAYASHI, MD, professor

Correspondence to: Dr Nakazawa.

\section{IgA nephropathy associated with mastitis and haematuria}

IgA nephropathy accounts for $18 \%$ of all cases of primary renal disease, and $60 \%$ of patients with the condition present with recurrent macroscopic haematuria. ${ }^{1}$ Episodic haematuria often occurs simultaneously with or is closely preceded by pharyngitis or vigorous exercise. We report a patient with IgA nephropathy in whom episodes of macroscopic haematuria showed a close temporal relation with mastitis.

\section{Case report}

A 32 year old woman presented with a four year history of microscopic haematuria, which had first been noted on routine analysis of urine during her last pregnancy. On four occasions over this period she had had episodes of mastitis with breast pain and fever accompanied by bilateral dull loin pain and followed within 12 hours by macroscopic haematuria; she was not lactating. All symptoms had resolved within 12 hours of the start of antibiotics on each occasion. Urine cultures were sterile. She had no history of arthralgias, rash, hypertension, or renal, hepatic, or bowel disease and was not taking any drugs. Physical examination yielded normal results, and her blood pressure was $130 / 70 \mathrm{~mm} \mathrm{Hg}$.

Quantitative urine microscopy during remission showed $1 \times 10^{\circ}$ red blood cells, 15000 granular casts, and 30000 red cell casts/l; the urine was sterile on culture. Serum creatinine concentration was $0.09 \mathrm{mmol} / 1(1 \mathrm{mg} / 100 \mathrm{ml})$, creatinine clearance $79.2 \mathrm{ml} / \mathrm{min}$, and urine protein loss $0.38 \mathrm{~g} /$ day. Total serum IgA concentration was raised at 4.08 (normal $0.70-3.12$ ) g/day with 